\title{
Analisis Kebutuhan Pengembangan $E$-Modul Bermuatan Video Pembelajaran pada Pendidikan Jarak Jauh bagi Calon Guru Fisika
}

\author{
Anggreini*, Dimas Permadi \\ Pendidikan Fisika, Universitas Lampung \\ *anggreini@fkip.unila.ac.id
}

\begin{abstract}
Distance Education (PJJ) as a learning solution during the COVID-19 pandemic at the University of Lampung has not been implemented optimally. The purpose of this study was to find out the circumstances and needs of prospective physics teacher students while carrying out PJJ online from their respective homes. As well as analyzing the materials and assignments to achieve the Subject Learning Outcomes (CPMK) of Educational Research Statistics. This study uses a descriptive analysis method with a research instrument in the form of a questionnaire distributed online with the help of a google form. The sample in this study was 53 students of physics teacher candidates in the Physics Education Study Program, University of Lampung. The results of this study indicate that the condition of students in implementing PJJ is that they already have adequate facilities both from electricity infrastructure, internet networks, devices, and getting support from family. However, students find it difficult to understand practical learning when using media and learning methods that are not varied. The analysis of materials and tasks developed from CPMK Educational Research Statistics consists of three main materials with ten learning videos, and each student is asked to complete matters an educational research case using SPSS. Based on the results of this needs analysis, lecturers need to develop a teaching material, namely an e-module containing learning videos that can facilitate prospective physics teacher students in implementing PJJ.
\end{abstract}

Keywords : Needs analysis, Teacher candidates, E-modules, Distance education, Learning videos

This is an open access article distributed under the Creative Commons 4.0 Attribution License, which permits unrestricted use, distribution, and reproduction in any medium, provided the original work is properly cited. $\odot 2021$ by author.

\section{PENDAHULUAN}

Seluruh dunia pada tahun 2020 mengalami wabah pandemi covid-19 yang berdampak terhadap semua bidang, termasuk bidang pendi dikan. Salah satu cara mengatasi penyebaran virus tersebut dengan melakukan gerakan social distancing untuk meminimalisir terjadinya inter aksi dalam jumlah yang banyak. Dengan adanya social distancing maka pembelajaran di pendi dikan formal menjadi terhambat dan tidak bisa dilakukan secara tatap muka. Lembaga pendidikan diharuskan menjalankan kegiatan belajarmengajar secara jarak jauh, meskipun peserta didik berada di rumah (Basar, 2020). Hal ini sejalan dengan salah satu isi pelaksanaan kebija kan pendidikan selama masa darurat penyebaran virus corona yang dikeluarkan oleh Menteri Pendidikan dan Kebudayaan, yaitu belajar dari rumah dengan proses belajar-mengajar dilaksana kan secara dalam jaringan (daring) atau jarak jauh (Surat Edaran No 4 tahun 2020). Oleh sebab itu bagi kawasan yang termasuk zona merah dan kuning selama pandemi covid-19 berlangsung, setiap lembaga pendidikan termasuk Universitas Lampung melaksanakan kegiatan Pendidikan Jarak Jauh (PJJ).

Peraturan Menteri Pendidikan dan Kebu dayaan Republik Indonesia Nomor 109 Tahun 2013 menjelaskan bahwa PJJ merupakan kegiatan pembelajaran yang dilaksanakan secara jarak jauh menggunakan berbagai media komunikasi dan informasi yang sumber belajarnya dikembangkan dari bahan ajar dan media pembelajaran yang dikemas dalam beragam bentuk dengan meman faatkan teknologi terkini. Sistem PJJ membuka akses terhadap pendidikan bagi siapa saja, di mana saja, dan kapan saja. Melalui sistem PJJ, setiap orang dapat memperoleh akses terhadap pendi dikan berkualitas tanpa harus meninggalkan keluarga, rumah, pekerjaan, dan tidak kehilangan kesempatan berkarir. PJJ merupakan solusi untuk memecahkan masalah keterbatasan ruang dan fasilitas dalam menerapkan social distancing di masa pandemi covid-19.

Sebagian besar proses PJJ saat ini masih memanfaatkan fasilitas grup Whatsapp dalam perangkat smart phone, serta untuk mengadakan 
tatap muka virtual dapat menggunakan aplikasi Google Classroom, Google meet, Zoom meeting (Arifa, 2020). Selanjutnya Universitas Lampung dalam rangka mendukung pelaksanaan PJJ full daring selama pandemi covid-19 terus memper baharui dan mengembangan Learning Mana gement Systems (LMS) yang dinamakan vclass. Vclass merupakan LMS yang dimiliki oleh Universitas Lampung, disana setiap dosen dapat membuat course sendiri serta add an activity or resource berupa forum diskusi, assignment, quiz, google meet, url atau file untuk mengakses perkuliahan secara sinkronus dan asinkronus.

Faktor penting yang dianggap memadai untuk mengembangkan suatu course dalam meng adopsi konsep pembelajaran dengan pendekatan Web-based adalah dalam diri dosen memiliki semangat dalam menggunakan teknologi (Weller, 2002; Porter, 1997). Pelaksanaan PJJ full daring tidak akan optimal jika hanya dilihat dari kemampuan dosen saja dalam mengembangkan $e$ learning, namun juga memerlukan dukungan dari petinggi institusi perguruan tinggi, melibatkan tim fasilitator yang terdiri dari staf dengan keahlian teknis, staf administratif, dan para mahasiswa (Darmayanti, Setiani, \& Oetojo, 2007). Oleh sebab itu, seluruh civitas akademisi dengan Dosen sebagai ujung tombaknya harus membuat PJJ semenarik mungkin untuk dilaksanakan secara sinkronus dan asinkronus.

Penyelenggaraan PJJ memiliki perbedaan yang signifikan dengan penyelenggaraan sistem pendidikan reguler, yang lebih menekankan pada pentingnya pertemuan atau pembelajaran tatap muka antara dosen dan mahasiswa. Dalam penyelenggaran $\mathrm{PJJ}$ terdapat berbagai macam kendala, diantaranya belum tersedia kurikulum yang tepat, pemerintah daerah belum menjelaskan secara rinci mengenai kegiatan PJJ, kesiapan sumber daya manusia (dosen, mahasiswa, dan tendik) serta masih terbatasnya ketersediaan sarana dan prasarana terutama dalam hal jaringan internet dan dukungan teknologi (Arifa, 2020; Sari dkk, 2020). Dari segi sumber daya manusia, terutama untuk dosen dan mahasiswa harus mampu merubah beberapa kebiasaan baik dalam menggunakan device dan jaringan internet, metode belajar mengajar, dan gaya komunikasi selama pembelajaran daring (Puspitorini, 2020). Dalam penyelenggaraan PJJ, penggunaan bahan ajar dan teknologi komunikasi memegang peranan yang sangat penting sebagai sarana penyampaian materi yang perlu dipelajari oleh mahasiswa (Pribadi \& Sjarif, 2010). Dengan alasan ini, dosen harus menyediakan bahan ajar serta metode belajar yang dapat dilaksanakan oleh mahasiswa baik secara sinkronus maupun asinkronus. Penelitian ini menargetkan produk berupa $e$ modul interaktif berisikan video pembelajaran yang dapat diakses secara offline atau online melalui smartphone, laptop, dan komputer serta sesuai dengan format penulisan bahan ajar LP3M Universitas Lampung.

PJJ dilaksanakan secara sinkronus diartikan sebagai interaksi yang berorientasi pada pembe lajaran real-time, difasilitasi oleh instruktur secara langsung, dan biasanya terjadwal (Suranto, 2019). Sedangkan PJJ daring yang dilaksanakan secara asinkronus, peserta didik secara independen dan fleksibel dalam memilih waktu berinteraksi dengan materi yang telah (Darmawan, 2018). Disamping itu penggunaan rekaman video memiliki keunggulan sebagai media pembelajaran asinkronus karena dapat diulang-ulang oleh mahasiswa untuk memahami materi perkuliahan (Didin, Fatin Saffanah dkk, 2020).

Pelaksanaan pembelajaran daring secara sinkronus dan asinkronus di Prodi Pendidikan Fisika Universitas Lampung menggunakan vclass sudah berjalan sejak Semester Ganjil 2020/2021. Namun pelaksanakan pembelajaran daring secara sinkronus dan asinkronus menggunakan vclass dinilai masih belum optimal. Saat pembelajaran dilaksanakan secara sinkronus, terkadang akses vclass masih sulit. Hal ini dikarenakan semua Fakultas di Universitas Lampung diminta untuk menggunakan $L M S$ tersebut, sehingga sering mengalami down dan menghambat perkuliahan daring jika dilaksanakan secara sinkronus. Jika pembelajaran dilakukan secara asinkronus, dosen baru memiliki buku cetak yang dinilai kurang efektif untuk pelaksanaan perkuliahan Statistika Penelitian Pendidikan yang di dalamnya terdapat kegiatan praktik menggunakan SPSS (Statistical Program for Social Science) dalam memecahkan kasus.

SPSS merupakan salah satu aplikasi yang sering digunakan dalam mengolah data. Menurut Jayadi \& Anwar (2017), SPSS dapat diartikan sebagai sebuah aplikasi analisis statistik yang dengan kemampuan cukup tinggi dan didukung sistem manajemen data dengan menggunakan menu-menu deskriptif dan inferensial dengan kemampuan perhitungan yang memudahkan pengguna dalam analisis data sehingga pengguna an aplikasi ini mampu meningkatkan minat dan motivasi mahasiswa untuk belajar statistika. Pengembangan pembelajaran statistika dengan 
aplikasi software SPSS dibantu dengan bantuan multimedia, yaitu disajikan bentuk tutorial (video) dalam menjalankan analisis data dengan SPSS dinilai dapat lebih mudah untuk dipahami oleh mahasiswa (Riyanto \& Nugrahanti, 2018). Oleh sebab itu, pelaksanaan PJJ secara sinkronus dan asinkronus untuk mata kuliah Statistika Penelitian Pendidikan diperlukannya video tutorial untuk mengoptimalkan proses pembelajaran.

Pelaksanaan PJJ kepada mahasiswa calon guru Fisika pada mata kuliah Statistika Penelitian Pendidikan mengikuti program Merdeka BelajarKampus Merdeka (MBKM) yang sedang dijalan kan oleh Kemendikbud dirancang untuk meme nuhi Indeks Kinerja Utama (IKU). Sesuai Keputusan Menteri Pendidikan dan Kebudayaan No. 754/P/2020 tentang Indikator Kinerja Utama Perguruan Tinggi Negeri Dan Lembaga Layanan Pendidikan Tinggi di Lingkungan Kementerian Pendidikan dan Kebudayaan telah mendorong perguruan tinggi untuk menyusun program kegiatan berorientasi pencapaian IKU yang di dalamnya juga mencantumkan kinerja PT dalam melaksanakan MBKM. Pembelajaran kelas (IKU 7) pada Mata Kuliah Statistika Penelitian Pendi dikan dirancang menggunakan metode pembe lajaran pemecahan kasus (case method) statistika pendidikan dengan aplikasi SPSS.

Poin-poin penting dalam penyusunan desain pembelajaran daring berbasis case method antara lain memerhatikan Capaian Pembelajaran Lulusan (CPL) Program Studi, sehingga pembe lajaran yang didesain sesuai dengan CPL dan menjawab kebutuhan dunia industri kerja. CPL kemudian dirumuskan menjadi Capaian Pembe lajaran Mata Kuliah (CPMK) Statistiska Pene litian Pendidikan. Indikator dan tujuan pembe lajaran perlu jabarkan untuk merancang materi ajar, aktivitas mahasiswa, media pembelajaran, sumber belajar dalam menerapkan metode case method.

Peraturan Rektor Universitas Lampung Nomor 22 Tahun 2020 mengatakan bahwa pembelajaran dalam PJJ diselenggarakan dengan memanfaatkan media pembelajaran berbasis ICT menggunakan bahan ajar dalam bentuk digital yang dikombinasikan dengan bahan ajar lain dalam beragam bentuk, format, media, dan sumber, sebagai sumber belajar yang dapat diakses kapan saja dan dari mana saja. Salah satu bahan ajar yang menunjang PJJ untuk mahasiswa calon guru Fisika yaitu $e$-modul bermuatan video pembelajaran.
Menurut Suarsana (2013) kelebihannya $e$ modul dibandingkan dengan modul cetak adalah sifatnya yang interaktif memudahkan dalam navigasi, memungkinkan menampilkan/memuat animasi gambar, audio, dan video serta memung kinkan adanya umpan balik otomatis dalam tes/kuis formatif. Hal ini dipertegas dengan beberapa penelitian yang menyimpulkan kelebih an e-modul diantaranya (Sugihartini \& Jayanta, 2017; Ummah dkk., 2018): ekonomis dalam segi anggaran, mudah dibawa, dan tidak mudah rusak dimakan waktu. Oleh karena itu, e-modul merupakan alternatif terbaik dalam pengembang an bahan ajar untuk PJJ dimana di dalamnya terdapat tujuan pembelajaran, materi, kegiatan pembelajaran, latihan, kuis, umpan balik yang dilengkapi dengan video pembelajaran.

Selanjutnya salah satu aplikasi yang dapat menunjang pembuatan $e$-modul yang didalamnya terdapat video pembelajaran untuk implementasi PJJ adalah flip pdf profesional. Aplikasi yang memungkinkan meletakkan multimedia dalam halaman buku seperti gambar dab video dari YouTube, hyperlink, kuis, animasi, dan lain-lain (Professional et al., 2019). Flip pdf professional (Sholikhatul Murtafiah, 2019; Yunianto dkk., 2019) adalah salah satu aplikasi untuk membuat bahan ajar yang dapat digunakan oleh semua orang, bahkan yang belum mahir mengoperasikan computer karena penggunaannya yang mudah.

Demi keterlaksanaan PJJ daring secara sinkronus dan asinkronus menggunakan case method yang optimal, peneliti menganalis keadaan dan kebutuhan mahasiswa selama melaksanakan PJJ menggunakan vclass sebagai dasar dalam mengembangkan $e$-modul bermuatan video pembe lajaran menggunakan flip pdf professional sebagai implementasi PJJ bagi mahasiswa calon guru Fisika. Kemenristekdiktik dalam Buku Panduan Pengisian Survey Pembelajaran Daring (2017) menjelaskan bahwa survey yang mereka lakukan berbentuk kuesioner terdiri dari 15 halaman, yang berisikan pengantar survei, daftar istilah, identitas responden, dilanjutkan dengan aspek-aspek yang akan dinilai diantaranya regulasi pembelajaran daring, implementasi pembelajaran daring, objek ajar, fasilitas dan sistem pendukung, sumber daya manusia, kerja sama dengan perguruan tinggi lain/asing. Selain itu Kementerian Pendidikan dan Kebudayaan tahun 2020 juga membuat Kuesioner Siswa Belajar dari Rumah yang terdiri dari 29 pertanyaan seputar pelaksanaan pembelajaran dalam masa darurat penyebaran covid-19. Berda sarkan hal tersebut peneliti mengembangan secara 
mandiri kuesioner terkait analisis kebutuhan dan keadaan mahasiswa calon guru Fisika dalam melaksanakan PJJ dengan pengembangkan sendiri indikator-indikator serta pertanyaan untuk menda patkan kondisi real mahasiswa calon guru Fisika dalam melaksanakan perkuliahan Statistika Peneli tian Pendidikan secara daring menggunakan vclass.

Urgensi penelitian ini bagaimana keadaan mahasiswa dalam melaksanakan perkuliahan daring dari rumah masing-masing serta hal apa saja yang diperlukan mahasiswa selama perkul iahan daring. Hal ini digunakan sebagai bahan kajian dosen dalam menganalisis materi untuk menentukan strategi perkuliahan, serta pengem bangan bahan ajar dan media pembelajaran berupa e-modul bermuatan video agar tetap optimal dan relevan. Tujuan penelitian ini adalah mendeskripsi kan hasil analisis kebutuhan maha siswa calon guru Fisika terhadap PJJ untuk mengembangkan $e$-modul bermuatan video pembelajaran. Pengem bangkan e-modul bermuatan video pembelajaran menggunakan menggunakan flip pdf professional sebagai implementasi PJJ bagi mahasiswa calon guru Fisika diharapkan dilaksanakan berdasarkan hasil analisis tersebut dan bagi peneliti lain dapat digunakan sebagai bahan rujukan.

\section{METODE PENELITIAN}

Jenis penelitian ini adalah penelitian deskriptif kualitatif. Penelitian dilakukan di Program Studi Pendidikan Fisika (PSPF) Universitas Lampung. Pengambilan sampel dilaku kan dengan teknik purposive sampling. Kriteria partisipan adalah mahasiswa calon guru Fisika yang sedang mengambil mata kuliah Statistika Penelitian Pendidikan, telah lebih dari satu semester menggunakan vclass secara sinkronus dan asinkronus selama PJJ daring. Berdasarkan kriteria tersebut terpilih 53 orang maha siswa PSPF yang dijadikan sampel pada penelitian ini.

Instrumen untuk tahap analisis berupa kuesioner dan lembar analisis. Analisis kebutuhan dan keadaan mahsiswa calon guru Fisika dalam melaksanakaan perkuliahan daring menggunakan survei yang dilakukan secara online melalui google form. Analisis kebutuhan dan keadaan mahasiswa selama melaksanakan PJJ daring dapat diidentifikasi dari pertanyaan tentang tempat mengakses PJJ, koneksi jaringan internet, kondisi infrastuktur listrik, kondisi jaringan internet, kondisi device, support keluarga, serta interaksi dan metode yang disenangi selama melaksanakan
PJJ. Sedangkan analisis materi dan tugas meng gunakan lembar analisis.

Teknik analisis data yang digunakan adalah teknik analisis data deskriptif, yaitu mendeskrip sikan hasil angket kuesioner kebutuhan dan keadaan mahasiswa serta hasil analisis materi dan tugas untuk mata kuliah Statistika Penelitian Pendi dikan. Data hasil penelitian dianalisis dengan menggunakan statistik deskriptif untuk mendapat kan nilai rata-rata dan persentase. Angket analisis kebutuhan dan keadaan maha siswa menggunakan skala likert. Kategori analisis kebutuhan keadaan mahasiswa calon guru Fisika dalam mengikuti PJJ daring diperoleh dengan cara menghitung skor dari setiap responden. Skor setiap responden diperoleh menggunakan persamaan 1 .

$\mathrm{S}_{\mathrm{k}}=\frac{\Sigma X_{i}}{X_{\max }} \times 100$

Keterangan:

$\mathrm{S}_{\mathrm{k}}=$ skor yang diperoleh

$\mathrm{X}_{\mathrm{i}}=$ skor setiap responden

$\mathrm{X}_{\max }=$ skor maksimum dari angket untuk setiap indikator

Analisis kebutuhan dilaksanakan pada tahap pertama pengembangan 4-D, yaitu define yang bertujuan untuk mengetahui permasalahan yang ditemukan untuk mengembangkan produk. Permasalahan yang ditemukan yaitu kebutuhan dan keadaan mahasiswa calon guru Fisika selama PJJ daring serta analisis materi dan tugas yang perlu dikembangkan sesuai dengan kebutuhan mahasiswa dan CPMK Statistika Penelitian Pendidikan. Prosedur penelitian ini memiliki beberapa tahap, yang ditunjukkan oleh Gambar 1.

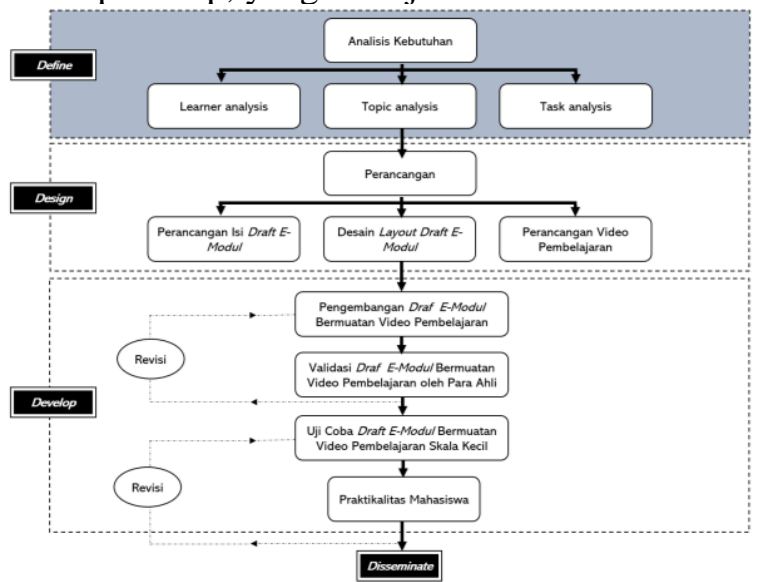

Gambar 1. Prosedur Pengembangan E-Modul Bermuatan Video Pembelajara Menggunakan Flip PDF Professional

Berdasarkan Gambar 1, terlihat bahwa pada penelitian ini yang menjadi fokus pembahasan pada tahap define. Learner analysis dilakukan untuk melihat keadaan dan kebutuhan mahasiswa 
calon guru dalam melaksanakan PJJ daring pada Mata Kuliah Statistika Penelitian Pendidikan. Topic analysis merupakan identifikasi materimateri utama yang diajarkan dan disusun secara sistematis serta mengkaitkan satu materi dengan materi yang relevan. CPMK dapat diukur jika materi yang diajarkan telah diidentifikasi secara tepat. Di samping itu, dengan mengidentifikasi jenis-jenis materi yang diajarkan, dosen dapat memilih metode dan media pembelajaran yang tepat digunakan selama PJJ. Selanjutnya task analysis dilakukan dosen untuk menganalisis tugas-tugas pokok yang harus dikuasai oleh mahasiswa melalui pemberian kasus statistika penelitian pendidikan untuk mencapai CPMK.

\section{HASIL DAN PEMBAHASAN}

Peneliti mengembangan secara mandiri kuesioner terkait analisis kebutuhan dan keadaan mahasiswa calon guru Fisika dalam melaksanakan PJJ daring. Kuesioner ini bertujuan untuk melihat keadaan mahasiswa dalam melaksanakan pembe lajaran daring dari tempatnya berada serta proses pembelajaran seperti apa yang diinginkan oleh mahasiswa pada mata kuliah Statistika Penelitian Pendidikan. Berikut ini hasil analisis keadaan dan kebutuhan mahasiswa calon guru Fisika saat melaksanakan PJJ:

\section{a. Tempat Mengakses PJJ}

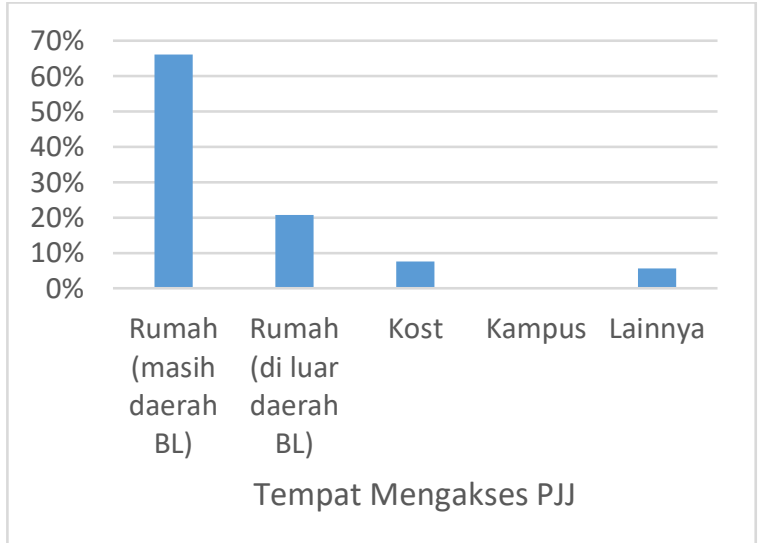

Gambar 2. Analisis Tempat Mahasiswa Mengakses PJJ

Berdasarkan data dalam Gambar 2 dapat dijelaskan bahwa lebih dari 50\% mahasiswa calon guru Fisika mengakses perkuliahan daring dari rumah masing-masing di luar daerah Bandar Lampung. Selain itu ada tiga orang yang mengakses PJJ dari asrama, rusunawa Unila, dan provinsi Jambi.

b. Koneksi Jaringan Internet

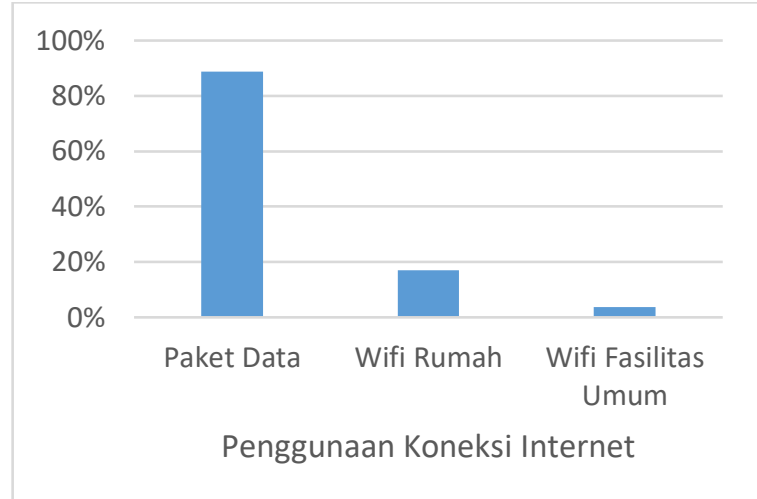

Gambar 3. Analisis Penggunaan Koneksi Internet

Berdasarkan Gambar 3 terlihat bahwa maha siswa cenderung mengakses perkuliahan daring menggunakan koneksi internet paket data. Hal ini ditunjang dengan adanya pemberikan kuota pendidikan gratis dari Kemendikbudristekdikti.

\section{c. Penggunaan Device}

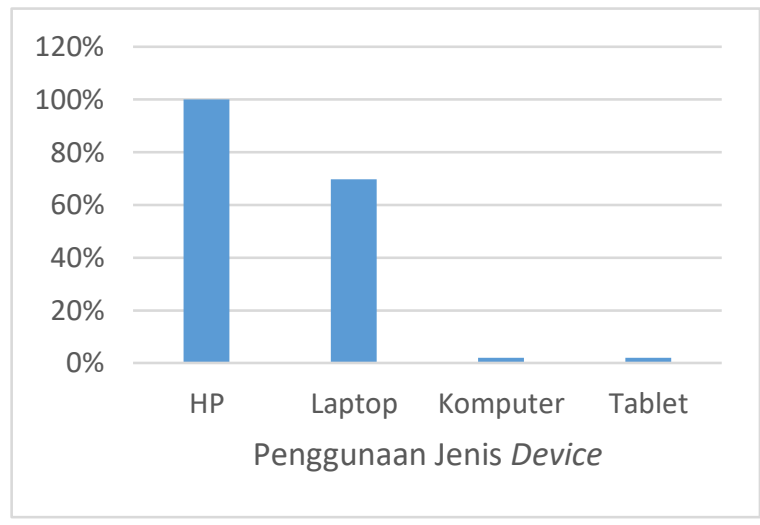

Gambar 4. Analisis Penggunaan Jenis Device

Pada survei penggunaan jenis device untuk mengakses perkuliahan daring mahasiswa diberi kan pilihan untuk bisa memilih lebih dari satu jenis device. Berdasarkan Gambar 4, terlihat bahwa mahasiswa memvariasiakan penggunaan HP dan Laptop untuk mengakses perkuliahan daring. Hal tersebut menjadi penunjang untuk mengikuti perkuliahan Statistika Penelitian Pendi dikan, karena setiap pertemuan adanya penyele saian kasus menggunakan SPSS yang lebih memadai jika diakses menggunakan laptop.

\section{d. Kondisi Infrastuktur Listrik, Jaringan} Internet, Device, dan Support Keluarga

Peneliti memberikan pernyataan mengenai kondisi infrastruktur listrik, jaringan internet di tempat mahasiswa melakukan PJJ serta kondisi device yang digunakan selama PJJ daring. Dari 53 
orang mahasiswa dengan respon terbanyak menjawab baik sebesar 71,1 untuk kondisi infrastruktur listrik, 76,9\% untuk kondisi jaringan internet, dan 60,4\% kondisi device serta 54,7\% untuk support keluarga. Sehingga dapat ditarik kesimpulan bahwa keadaan mahasiswa dalam melaksanakan perkuliahan daring yaitu sudah memiliki fasilitas yang memadai baik dari infrastruktur listrik, jaringan internet, device serta mendapatkan support dari keluarga.

e. Motivasi dan Keterampilan Mengikuti Perkuliahan Daring

Tabel 1. Hasil Analisis Motivasi dan

Keterampilan Mahasiswa Selama Melaksanakan Perkuliahan Daring

\begin{tabular}{|c|c|c|c|}
\hline $\begin{array}{l}\mathbf{N} \\
\mathbf{0}\end{array}$ & Pertanyaan & $\begin{array}{c}\text { Responses } \\
\text { Terbanyak }\end{array}$ & $(\%)$ \\
\hline 1 & $\begin{array}{l}\text { Saya merasa senang } \\
\text { mengikuti } \\
\text { perkuliahan daring }\end{array}$ & Setuju & 45,3 \\
\hline 2 & $\begin{array}{l}\text { Saya merasa bosan } \\
\text { dan tidak bersema } \\
\text { ngat mengikuti perku } \\
\text { liahan daring jika } \\
\text { menggunakan meto } \\
\text { tode yang itu-itu saja }\end{array}$ & Setuju & 37,7 \\
\hline 3 & $\begin{array}{l}\text { Saya mudah } \\
\text { mendapatkan sumber } \\
\text { belajar selama proses } \\
\text { perkuliahan daring }\end{array}$ & Setuju & 45,3 \\
\hline 4 & $\begin{array}{l}\text { Tetap bisa } \\
\text { berkonsentrasi saat } \\
\text { belajar dari rumah }\end{array}$ & Setuju & 49,1 \\
\hline 5 & $\begin{array}{l}\text { Saya tidak } \\
\text { mengalami kesulitan } \\
\text { dalam mengakses } \\
\text { perkuliahan di Vclass } \\
\text { Unila }\end{array}$ & Setuju & 47,2 \\
\hline 6 & $\begin{array}{l}\text { Activities (upload } \\
\text { tugas, chat, forum, } \\
\text { kuis dll) dan } \\
\text { Resources (download } \\
\text { buku, download file } \\
\text { bahan aja) pada } \\
\text { Vclass mudah untuk } \\
\text { diakses }\end{array}$ & Setuju & 52,8 \\
\hline
\end{tabular}

Berdasarkan Tabel 1, dapat disimpulkan bahwa mahasiswa masih kesulitan dalam meng akses perkuliahan di vclass, mendapatkan sumber belajar, dan merasa bosan serta tidak bersemangat mengikuti perkuliahan daring jika menggunakan metode yang itu-itu saja.

f. Interaksi yang Disenangi Mahasiswa Selama Pelaksanaan Perkuliahan Daring

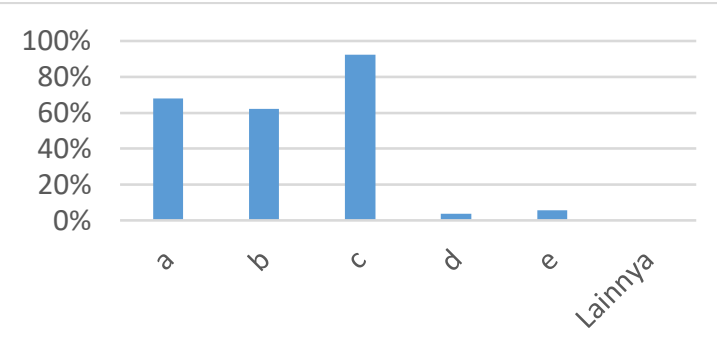

Interaksi yang Disenangi Mahasiswa...

Gambar 5. Analisis Interaksi yang Disenangi Mahasiswa Selama Pelaksanaan Perkuliahan Daring

Keterangan Interaksi:

$\mathrm{a}=$ Interaksi melalui kelas online yang dise diakan dosen (Vclass, forum siakadu, dll)

$\mathrm{b}=$ Interaksi melalui media sosial (Whatsapp Group dsb)

c $=$ Interaksi melalui video conference yang disediakan dosen (Google meet, Zoom, dll)

$\mathrm{d}=$ Interaksi melalui email

$\mathrm{e}=$ Interaksi melalui telepon/chat pribadi $\mathrm{Wa}$

g. Metode Pembelajaran yang Disenangi Mahasiswa Selama Pelaksanaan Perkuliahan Daring

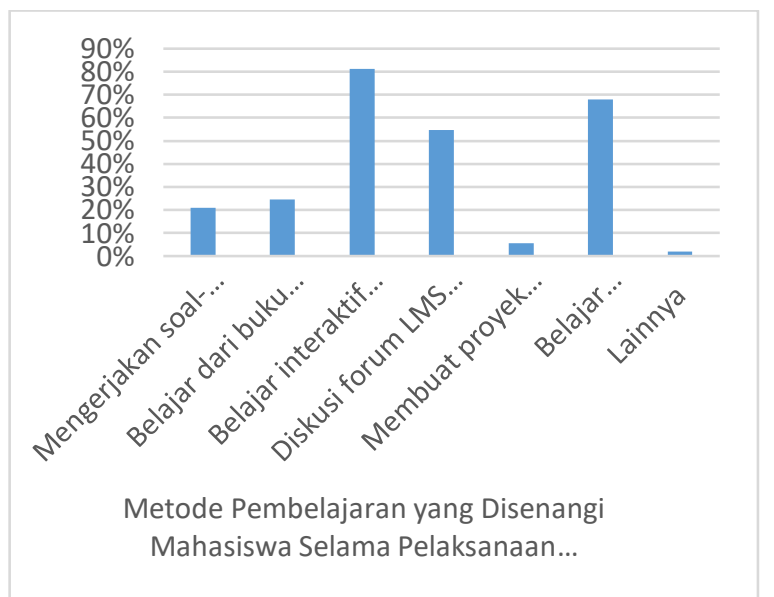

Gambar 6. Analisis Metode Pembelajaran yang Disenangi Mahasiswa Selama Pelaksanaan Perkuliahan Daring

h. Metode Belajar yang Disenangi Mahasiswa untuk Pelaksanaan Perkuliahan Praktik Menggunakan SPSS 


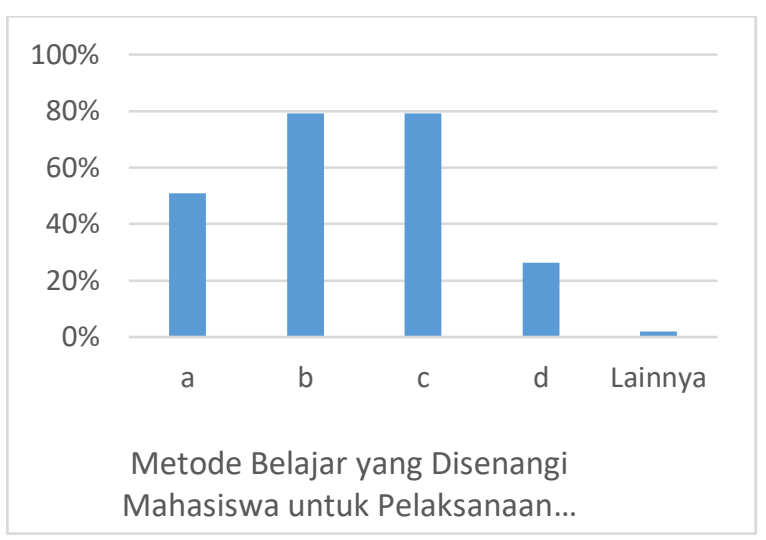

Gambar 7. Metode Belajar yang Disenangi

Mahasiswa untuk Pelaksanaan Perkuliahan Praktik Menggunakan SPSS

Keterangan Interaksi:

$$
\begin{aligned}
& \mathrm{a}= \begin{array}{l}
\text { Membaca dan memahami tahap-tahap } \\
\text { dari modul yang telah diberikan }
\end{array} \\
& \text { kemudian melakukannya }
\end{aligned}
$$

Mahasiswa diberikan kesempatan untuk memilih lebih dari satu pilihan mengenai bentuk interaksi dan metode pembelajaran yang disenangi selama perkuliahan daring. Berdasarkan Gambar 5 , 6, dan 7 terlihat bahwa mahasiswa menyukai perkuliahan dengan interaksi dan metode pembe lajaran yang bervariatif, baik itu secara sinkronus menggunakan video conference atau secara asinkronus di forum vclass. Selanjutnya untuk perkuliahan Statistika Penelitian Pendidikan yang terdapat kegiatan praktik menggunakan SPSS, mahasiswa menyukai jika dilaksanakan dengan menonton video tutorial atau mendengarkan penjelasan dari dosen secara langsung kemudian mempraktekkannya. Interaksi dan metode pembe lajaran ini dapat difasilitasi dengan pengem bangan bahan ajar berupa e-modul bermuatan video pembelajaran pemecahan kasus mengguna kan SPSS.

Kegiatan kedua yang dilakukan pada tahap define yaitu analisis materi dan analisis tugas. Mata kuliah Statistika Penelitian Pendidikan di Program Studi Pendidikan Fisika (PSPF) terdiri dari enam buah sub CPMK. Penelitian ini mengembangan $e$-modul bermuatan video pembe

\begin{tabular}{|c|c|c|c|}
\hline $\begin{array}{c}\text { Topic } \\
\text { Analysis }\end{array}$ & $\begin{array}{c}\text { Sub } \\
\text { Topik }\end{array}$ & $\begin{array}{c}\text { Video } \\
\text { Pembelaja } \\
\text { ran } \\
\end{array}$ & $\begin{array}{c}\text { Task } \\
\text { Analy sis }\end{array}$ \\
\hline $\begin{array}{l}\text { Statistika } \\
\text { Deskriptif }\end{array}$ & $\begin{array}{l}\text { Analisis } \\
\text { Statistika } \\
\text { Deskriptif }\end{array}$ & $\begin{array}{l}\text { Cara Memba } \\
\text { ngun Data } \\
\text { pada Aplikasi } \\
\text { SPSS } \\
\text { Uji Analisis } \\
\text { Statistika } \\
\text { Deskriptif } \\
\text { Uji } \\
\text { Normalitas } \\
\text { Data }\end{array}$ & $\begin{array}{l}\text { Merumus } \\
\text { kan serta } \\
\text { menyelesai } \\
\text { kan suatu } \\
\text { kasus } \\
\text { penelitian } \\
\text { pendidikan } \\
\text { terkait uji } \\
\text { normalitas } \\
\text { data } \\
\text { mengguna } \\
\text { kan SPSS }\end{array}$ \\
\hline $\begin{array}{l}\text { Uji Beda } \\
\text { Rata-rata } \\
\leq \text { Dua } \\
\text { Sampel }\end{array}$ & $\begin{array}{l}\text { Uji Beda } \\
\text { Satu } \\
\text { Sampel } \\
\text { Uji Beda } \\
\text { Dua } \\
\text { Sampel } \\
\text { Berpasang } \\
\text { an } \\
\text { Uji Beda } \\
\text { Dua } \\
\text { Sampel } \\
\text { Bebas }\end{array}$ & $\begin{array}{l}\text { Cara } \\
\text { Menghitung } \\
\text { Nilai N-Gain } \\
\text { Menggunakan } \\
\text { SPSS } \\
\text { Uji } \\
\text { Independent } \\
\text { Sample T- } \\
\text { Test }\end{array}$ & $\begin{array}{l}\text { Merumus } \\
\text { kan serta } \\
\text { menyelesai } \\
\text { kan suatu } \\
\text { kasus } \\
\text { penelitian } \\
\text { pendidikan } \\
\text { terkait } \\
\text { pengujian } \\
\text { proporsi } \\
\text { dan } \\
\text { kesamaan } \\
\text { dua } \\
\text { proporsi } \\
\text { mengguna } \\
\text { kan SPSS }\end{array}$ \\
\hline $\begin{array}{l}\text { Uji Beda } \\
\text { Lebih dari } \\
\text { Dua } \\
\text { Sampel }\end{array}$ & $\begin{array}{l}\text { Uji } \\
\text { Perbanding } \\
\text { an Ganda }\end{array}$ & $\begin{array}{l}\text { Uji } \\
\text { Normalitas } \\
\text { Uji } \\
\text { Homogenitas } \\
\text { Dan One Way } \\
\text { Anova } \\
\text { Uji Multiple } \\
\text { Comparison }\end{array}$ & $\begin{array}{l}\text { Merumusk } \\
\text { an serta } \\
\text { menyelesai } \\
\text { kan suatu } \\
\text { kasus } \\
\text { penelitian } \\
\text { pendidikan } \\
\text { terkait } \\
\text { pengujian } \\
\text { variansi } \\
\text { mengguna } \\
\text { kan SPSS }\end{array}$ \\
\hline
\end{tabular}
lajaran untuk sub CPMK ke-4. Berikut hasil analisis materi dan tugas mata kuliah Statistika Penelitian Pendidikan yang dikembangankan menjadi e-modul bermuatan video pembelajaran.

Tabel 2. Topic Analysis dan Task Analysis Mata Kuliah Statistika Penelitian Pendidikan untuk Sub CPMK Mampu merangkum mengenai pengujian hipotesis statistik terkait normalitas data, rata-rata, dan variansi parsial

Berdasarkan hasil analisis materi dan tugas untuk Sub CMPK Mampu merangkum mengenai pengujian hipotesis statistik terkait normalitas data, rata-rata, dan variansi parsial, dapat dijabarkan menjadi tiga materi pokok yaitu statistika deskriptif, uji beda rata-rata $\leq$ dua sampel, dan uji beda lebih dari dua sampel. 
Merangkum hasil analisis kebutuhan, analisis materi dan tugas, mahasiswa calon guru Fisika dalam melaksanakan perkuliahan PJJ daring menginginkan adanya variasi interaksi dan metode pembelajaran dalam menyelesaikan kasus mata kuliah Statistika Peneltian Pendidikan. Mengatasi hal tersebut, dipenelitian selanjutnya peneliti akan mengembangkan bahan ajar dan media pembelajaran berupa e-modul bermuatan video pembelajaran yang dapat menunjang pembelajaran daring secara sinkronus dan ansinkronus untuk calon guru Fisika.

PJJ bukanlah hal yang baru dalam pelaksanaan proses pendidikan formal di Indonesia. Univeritas Terbuka menjadi salah satu pelopor pelaksanaan PJJ. PJJ menjadi solusi permasalah pelaksanaan pembelajaran daring dimasa covid-19. Penelitian yang dilakukan oleh Satrianingrum dan Prasetyo (2020) mengatakan bahwa pembelajaran daring memberikan manfaat yang luas, yakni dapat menjangkau ke seluruh wilayah Indonesia, yang mana penyebaran dan keterjangkauan layanan internet yang menjadi lamban sewaktu-waktu. Penelitian lain menunjuk kan adanya kendala yang ditemukan selama pembelajaran daring, yakni kurangnya support orang tua dalam memberikan fasilitas PJJ daring, jaringan internet sulit diakses dari linkungan tempat tinggal dan membutuhkan biaya yang tidak sedikit serta kurangnya motivasi dan disiplin dari diri sendiri (Jones, \& Sharma, 2019; Bao, 2020; Obiakor, \& Adeniran, 2020; Purwanto, Pramono, Asbari, Santoso, Wijayanti, \& Hyun, 2020). Hal tersebut sangat berbeda dengan hasil penelitian yang ditemukan, yaitu mahasiswa calon guru Fisika mengakses PJJ daring berada di daerah yang tersebar di provinsi Lampung dan satu orang berada di provinsi Jambi, dimana mereka memiliki fasilitas internet yang baik sehingga dapat mengakses perkuliahan secara sinkronus dan asinkronus. Dimana 89\% diantaranya meng gunakan koneksi internet paket data. Hal ini ditunjang dengan adanya pemberikan kuota pendidikan gratis dari Kemendikbudristekdikti sebesar $15 \mathrm{~GB} /$ bulan yang dapat digunakan untuk mengakses seluruh laman dan aplikasi kecuali yang diblokir oleh Kementerian Komunikasi dan Informatika (Kemenkominfo).

PJJ yang dilaksanakan dari rumah masingmasing membuat para orang tua lebih mudah dalam memonitoring kegiatan mahasiswa secara langsung. Orang tua mengetahui sejauh mana kompetensi dan kemampuan anak mereka selama melaksanakan PJJ daring (Puspitorini, 2020). Support orang tua dan keluarga dalam memfasi litasi mahasiswa mengikuti perkuliahan daring terlihat dari setiap mahasiswa PSPF memiliki device yang mendukung akses perkuliahan daring serta dapat berkonsentrasi mengikuti perkuliahan dari rumah tanpa adanya gangguan dari lingkung an tempat tinggal. Mahasiswa PSPF dalam melaksnakan PJJ daring telah menggunakan device berupa $\mathrm{hp}$ dan laptop yang tentunya menunjang untuk pelaksanaan perkuliahan Statis tika Penelitian Pendidikan berupa pemecahan kasus menggunakan aplikasi SPSS.

Interaksi PJJ daring memang tidak sesempurna perkuliahan di kelas secara langsung, hal tersebut mengakibatkan kejenuhan kuliah online bagi dosen dan mahasiswa jika dilaksana kan terus-menurus dalam jangka waktu panjang. Rasakejenuhan yang tidak cepat diatasi, akan menyebabkan tidak proses belajar-mengajar menjadi tidak optimal yang mengakibatkan tidak memuaskannya hasil pembelajaran yang diper oleh. Hal ini dapat diatasi dengan Pengaturan waktu perkuliahan yang lebih fleksibel oleh dosen dan mahasiswa (Indrawati, 2020). Hal ini juga terjadi pada mahasiswa calon guru Fisika saat mengikuti perkuliahan Statistika Penelitian Pendi dikan, mereka menginginkan perkuliahan dengan berbagai variasi metode dan interaksi saat pelaksaan PJJ daring baik secara sinkronus dan asinkronus. Tentunya variasi metode dan interaksi selama proses pembelajaran harus didukung dengan bahan ajar dan media pembelajaran yang dapat digunakan dikedua kondisi tersebut.

PJJ selama masa covid-19 memang sangat bergantung pada berbagai media dan teknologi. Media yang digunakan dalam PJJ dapat berupa bahan cetak, siaran radio, siaran televisi, konferensi komputer, email, video interaktif, dan teknologi komputer multimedia (Susanti \& Halimah, 2018). Hal ini sebelumnya telah diper tegas oleh Peraturan Menteri Pendidikan dan Kebudayaan Nomor 109 Tahun 2013 Pasal 7 berisi proses penyelenggaraan PJJ salah satunya dengan cara menggunakan bahan ajar dalam bentuk elektronik yang dikombinasikan dengan bahan ajar lain dalam beragam bentuk, format, media, dan sumber.

Solusi yang dapat ditawarkan untuk memenuhi kebutuhan bahan ajar untuk pelaksana 
an PJJ daring yaitu mengembangkan e-modul. Emodul dapat menjadi bahan ajar alternatif yang dapat menunjang perkuliahan daring mahasiswa. E-modul merupakan salah satu bahan ajar berbasis elektronik yang dikemas sistematis, interaktif, dan lebih menarik dengan adanya gambar, audio, maupun video agar mudah dipahami untuk mencapai kompetensi mata kuliah yang diharap kan (Imansari \& Sunaryantiningsih, 2017; Ricu Sidiq \& Najuah, 2020). Ketersediaan video pembelajaran serta rangkuman materi dalam emodul yang dikembangkan dapat meningkatkan motivasi belajar dan memudahkan mahasiswa memahami inti materi pada setiap kegiatan pembelajaran (Retnosari \& Hakim, 2021). Selan jutnya materi yang diharapkan terdapat dalam video hanya berupa poin-point penting, ringkas, padat, dan sistematis sehingga tidak memakan durasi yang lama karena mempertimbangkan pikiran mahasiswa agar tetap fokus (Susanti \& Halimah, 2018). Berdasarkan hal tersebut diharap kan untuk penelitian selanjutnya peneliti dapat mengembangkan produk berupa $e$-modul interak tif berisikan video pembelajaran yang dapat diakses melalui smartphone, laptop, dan komputer serta sesuai dengan format penulisan bahan ajar LP3M Universitas Lampung.

\section{KESIMPULAN}

Analisis kebutuhan mahasiswa calon guru pendidikan Fisika terhadap pelaksanaan PJJ dilakukan melalui beberapa analisis yaitu analisis kebutuhan, analisis materi, dan analisis tugas. Keadaan mahasiswa dalam melaksanakan PJJ yaitu sudah memiliki fasilitas yang memadai baik dari infrastruktur listrik, jaringan internet, device serta mendapatkan support dari keluarga. Namun mahasiswa merasa kesulitan dalam memahami pembelajaran praktik jika menggunakan media dan metode pembelajaran yang tidak variatif. Analisis materi dan tugas yang dikembangkan dari CPMK Statistika Penelitian Pendidikan terdiri dari tiga materi pokok dengan sepuluh video pembelajaran, serta masing-masing sub materi pokok mahasiswa diminta untuk menyelesaikan suatu kasus penelitian pendidikan menggunakan SPSS.

\section{DAFTAR PUSTAKA}

Arifa, F N. (2020). Tantangan Pelaksanaan Kebijakan Belajar dari Rumah dalam Masa Darurat Covid-19. Bidang Kesejahteraan Sosial Kajian Singkat Terhadap Isu Aktual Dan Strategi, 12 (1), 1-7.

Bao, W. (2020). COVID-19 and Online Teaching in Higher Education: A Case Study Of Peking University. Pedagogical Research, 5(4), 113-115.

Basar, A M. (2020). Problematika Pembelajaran Jarak Jauh Pada Masa Pandemi Covid-19. EDUNESIA: Jurnal Ilmiah Pendidikan, Vol. 2 No. 1.

Darmawan, E. (2018). Implementasi Model Pembelajaran Asynchronous Dalam Peran cangan Aplikasi Simulasi Panduan Pecinta Alam Berbasis Android. Cloud Information Journal: Journal of Information System, Vol 3, No 2.

Darmayanti, T., Setiani, M. Y., \& Oetojo, B. (2007). E-Learning Pada Pendidikan Jarak Jauh: Konsep yang Mengubah Metode Pembe lajaran Di Perguruan Tinggi Di Indonesia. Jurnal Pendidikan Terbuka dan Jarak Jauh, 8(2), 99-113.

Didin, Fatin Saffanah., Mardiono, Intan., \& Yanuarso, Hersa Dwi. (2020). Analisis Beban Kerja Mental Mahasiswa saat Perkuliahan Online Synchronous dan Asyn chronous Menggunakan Metode Rating Scale Mental Effort. Jurnal OPSI, 13 (1).

Imansari, N., \& Sunaryantiningsih, I. (2017). Pengaruh Penggunaan E-Modul Interaktif Terhadap Hasil Belajar Mahasiswa pada Materi Kesehatan dan Keselamatan Kerja. VOLT: Jurnal Ilmiah Pendidikan Teknik Elektro, 2(1), 11.

Indrawati, B. (2020). Tantangan dan Peluang Pendidikan Tinggi Dalam Masa dan Pasca Pandemi Covid-19. Jurnal Kajian Ilmiah, 1(1), 39-48.

Jayadi, A., \& Anwar, Z. (2017). Pemanfaatan Aplikasi SPSS untuk Meningkatkan Keterampilan Mahasiswa Mengolah Data Statistika. Jurnal Visionary, 4(2), 111-113.

Jones, K., \& Sharma, R. (2019). Reimagining a future for online learning in the postCOVID era. SSRN Electronic Journal.

Keputusan Menteri Pendidikan dan Kebudayaan No. 754/P/2020 tentang Indikator Kinerja Utama Perguruan Tinggi Negeri Dan Lembaga Layanan Pendidikan Tinggi di 
Lingkungan Kementerian Pendidikan dan Kebudayaan.

Obiakor, T., \& Adeniran, A. (2020). COVID-19: Impending Situation Threatens to Deepen Nigeria's Education Crisis. Center for the Study of the Economi of Africa, 1-7.

Peraturan Menteri Pendidikan Dan Kebudayaan Republik Indonesia Nomor 109 Tahun 2013 Tentang Penyelenggaraan Pendidikan Jarak Jauh Pada Pendidikan Tinggi.

Peraturan Rektor Universitas Lampung Nomor 22 Tahun 2020 tentang Pendidikan Jarak Jauh.

Porter, L.R. (1997). Creating The Virtual Class room: Distance Learning with The Internet. New York: John Wiley \& Sons.

Pribadi, B. A., \& Sjarif, E. (2010). Pendekatan konstruktivistik dan Pengembangan Bahan Ajar pada Sistem Pendidikan Jarak Jauh. Jurnal Pendidikan Terbuka dan Jarak Jauh, 11(2), 117-128.

Professional, F. P. D. F., Flip, W., Professional, P. D. F., Windows, F., Service, O., \& Upgrade, P. 2019. Flip PDF Professional Interactive publishing - add video, image, link and.

Purwanto, A., Pramono, R., Asbari, M., Santoso., P. B., Wijayanti, L. M., Hyun, C. C., et al. (2020). Studi Eksploratif Dampak Pandemi COVID-19 Terhadap Proses Pembelajaran Online di Sekolah Dasar. Journal of Education, Psychology, and Counseling, 2, $1-9$.

Puspitorini, F. (2020). Strategi Pembelajaran Di Perguruan Tinggi Pada Masa Pandemi Covid-19. Jurnal Kajian Ilmiah, 1(1), 99106.

Retnosari, D. S., \& Hakim, Luqman. (2021). EModul Interaktif Perbankan Syariah Sebagai Bahan Ajar Alternatif dalam Menunjang Perkuliahan Daring Mahas iswa. Jurnal Penelitian dan Pengembangan Pendidikan, 5 (2), 206-214.

Ricu Sidiq, \& Najuah. (2020). Pengembangan EModul Interaktif Berbasis Android pada Mata Kuliah Strategi Belajar Mengajar. Jurnal Pendidikan Sejarah, 9(1), 1-14.

Riyanto, S. dan F. N. (2018). Pengembangan Pembelajaran Statistika Berbasis Praktikum Aplikasi Software SPSS dengan Bantuan Multimedia untuk Mempermudah Pema haman Mahasiswa terhadap Ilmu Statistika. Journal of Computer and Information Technology, 1(2), 62-67.
Sari, W., Rifki, A. M., \& Karmila, M. (2020). Pembelajaran Jarak Jauh Pada Masa Darurat Covid 19. Jurnal Mappesona, 2(1), $1-13$.

Satrianingrum, A. P., \& Prasetyo, I. (2021). Persep si Guru Dampak Pandemi Covid-19 terhadap Pelaksanaan Pembelajaran Daring di PAUD. Jurnal Obsesi: Jurnal Pendidik an Anak Usia Dini, 5 (1), 633-640.

Sholikhatul Murtafiah, S. (2019). Pengembangan E-Modul KD Menerapkan Pembuatan Website Kelas XI BDP di SMKN 1 Jombang. Jurnal Pendidikan Tata Niaga (JPTN), 7(2).

Suarsana, I. M., \& Mahayukti, G.A. (2013). Pengembangan E-Modul Berorientasi Peme cahan Masalah Untuk Meningkatkan Kete rampilan Berpikir Kritis Mahasiswa. Jurnal Pendidikan Indonesia, 2 (2).

Sugihartini, N., \& Jayanta, N. L. (2017). E-Modul Strategi Pembelajaran Berbasis CAI dengan Project Based Learning (Kajian Respon Pengguna Sistem). Seminar Nasional Riset Inovatif, 5, 831-838.

Suranto, B. (2019). Virtual Classroom: Strategi Pembelajaran Berbasis Synchronous ELearning. Seminar Nasional Aplikasi Tekno logi Informasi (SNATI).

Surat Edaran Nomor 4 Tahun 2020 tentang Pelaksanaan Kebijakan Pendidikan dalam Masa Darurat Penyebaran Covid-19.

Susanti, E., \& Halimah, M. (2018). Desain Video Pembelajaran yang Efektif Pada Pendidikan Jarak Jauh: Studi Di Universitas Terbuka. Jurnal Pendidikan Dan Kebudayaan, 3 (2), 167-185.

Tim Kemenristekdiktik. (2017). Buku Panduan Pengisian Survey Pembelajaran Daring. Jakarta: Kemenristekdiktik.

Ummah, R., Suarsini, E., \& Lestari, S. R. (2018). Analisis Kebutuhan Pengembangan EModul Berbasis penelitian Uji Antimikroba pada Matakuliah Mikrobiologi. Seminar Nasional Pendidikan IPA 2017, 2.

Weller, M. (2002). Delivering learning on the net: The why, what $\&$ how of on line education. London: Kogan Page. 